\title{
Potential Impact of the Free Trade Area of the Americas on the U.S. Sugarcane Industry 1
}

José Alvarez ${ }^{2}$

Countries and regions are moving to liberalize trade throughout the world. Many bilateral and multilateral agreements have been signed in the past few years and others are under negotiation. The Free Trade Area of the Americas (FTAA) is currently being negotiated. As in every trade agreement, the FTAA is likely to produce winners and losers. The U.S. sugar industry appears to be among the losers. The objective of this fact sheet is to describe the general characteristics of the FTAA and explore its potential negative impacts on the U.S. sugar industry.

\section{General Characteristics of the FTAA}

\section{Participant Countries}

Current negotiations involve the following 34 countries: Antigua and Barbuda, Argentina, Bahamas, Barbados, Belize, Bolivia, Brazil, Canada, Chile, Colombia, Costa Rica, Dominica, Dominican Republic, Ecuador, El Salvador, Grenada, Guatemala, Guyana, Haiti, Honduras, Jamaica, Mexico, Nicaragua, Panama, Paraguay, Peru, St. Kitts and Nevis, St. Lucia, St. Vincent and the Grenadines,
Suriname, Trinidad and Tobago, United States, Uruguay, and Venezuela.

It is important to note that 24 countries on that list are participating in the U.S. sugar program (http://edis.ifas.ufl.edu/SC020; http://edis.ifas.ufl.edu/SC056) and hold tariff-rate quotas (TRQ). In the 2002-03 fiscal year, they were allocated 742,995 of a total 1,117,195 metric tons of raw cane sugar, which represents 66.5 percent of the total (calculated from Haley and Suarez, 2004, p. 45). Since those countries benefit from the tariff rents that derive from the allocation of TRQs under the current U.S. sugar program, the elimination of such a program may not be advantageous for them (Moss and Schmitz, 2002).

\section{Organization of the Negotiations}

FTAA negotiations started in December 1994 with the goal of implementing the agreement in December 2005. Up to now, the negotiations have proceeded according to schedule (Table 1).

Preliminary discussions led to the organization of the negotiations under nine groups:

1. This is EDIS document FE563, a publication of the Department of Food and Resource Economics, Florida Cooperative Extension Service, Institute of Food and Agricultural Sciences, University of Florida, Gainesville, FL. Published June 2005. This publication is also part of the Florida Sugarcane Handbook, a publication of the Department of Agronomy, University of Florida, Gainesville, FL. For more information, contact the editor of the Sugarcane Handbook, Dr. R.A. Gilbert (ragilbert@ifas.ufl.edu), Everglades REC, Belle Glade, FL 33430. Please visit the EDIS website at http://edis.ifas.ufl.edu.

2. José Alvarez, Adjunct and Emeritus Professor, Department of Food and Resource Economics, Everglades Research and Education Center, Belle Glade, FL, Florida Cooperative Extension Service, Institute of Food and Agricultural Sciences, University of Florida, Gainesville, FL.

The Institute of Food and Agricultural Sciences (IFAS) is an Equal Opportunity Institution authorized to provide research, educational information and other services only to individuals and institutions that function with non-discrimination with respect to race, creed, color, religion, age, disability, sex, sexual orientation, marital status, national origin, political opinions or affiliations. U.S. Department of Agriculture, Cooperative Extension Service, University of Florida, IFAS, Florida A. \& M. University Cooperative Extension Program, and Boards of County Commissioners Cooperating. Larry Arrington, Dean 
1. Agriculture

2. Market access

3. Investment

4. Services

5. Government procurement

6. Dispute settlement

7. Intellectual property rights

8. Subsidies, antidumping, and countervailing duties

9. Competition policy

\section{Potential Impacts of the FTAA on U.S. Agriculture}

The Economic Research Service (ERS, 2004, pp. iii-iv) lists ten general implications of the FTAA on U.S. agriculture:

1. An annual increase in U.S. global agricultural exports and imports of about $\$ 1$ billion each.

2. An annual increase in agricultural trade in the Western Hemisphere of about $\$ 4$ billion (6 percent).

3. An annual increase of about $\$ 63$ billion in welfare (consumer purchasing power) in the Western Hemisphere as a result of the liberalization of both agricultural and manufactured goods.

4. A small effect on U.S. agricultural production because trade with the Western Hemisphere accounts for only a small share of aggregate output and U.S. tariffs are already low.

5. Additional agricultural benefits to those from trade agreements already completed in the Western Hemisphere, mainly from NAFTA.

6. Further reductions on tariffs remaining on some products in the Western Hemisphere despite the previous agreements.

7. An expansion of U.S. market potential for foreign direct investment in processed foods.
8. Small benefits on U.S. agri-environment in terms of decreased soil erosion and water pollution from nitrogen and also in environmental costs.

9. No difference in sanitary and phytosanitary issues from those in the World Trade

Organization (WTO).

10. A mutual reinforcement of trade liberalization strategies between the Doha Development Agenda (developed at the WTO Ministerial Meeting held in November 2001 in Doha, Qatar) and the FTAA.

\section{Potential Impacts of the FTAA on U.S. Cane Sugar}

Before considering several potential scenarios of increased imports of sugar into the United States, Haley (2004) discusses the cost structures of Western Hemisphere sugar-producing sectors, and their ability to supply the U.S. market. ${ }^{3}$ The projections made are based on the USDA sugar projections baseline model. ${ }^{4}$

\section{Background Information}

\section{Cost of Sugar Production}

Sugar production costs of potential competitors in the Western Hemisphere are contained in a study conducted by LMC International (2000) for the 1998-99 crop. Three groups of countries can be found within the proposed free trade area: ${ }^{5}$

1. The lowest-cost producers (average cost at 7.7 cents per pound) include central/south Brazil, Colombia, El Salvador, and Guatemala, accounting for about 48 percent of total hemispheric production.

2. Bolivia, north/east Brazil, Costa Rica, Ecuador, Mexico, Nicaragua, and Florida-USA averaged 12.34 cents per pound, accounting for around 32 percent of total hemispheric production.

3. Argentina, Belize, Guyana, Honduras, Panama, Paraguay, Peru, Louisiana-USA, and Texas-USA averaged 16.54 cents per pound, contributing approximately 15 percent to total output. 
The cane-sugar producing areas of the United States (Louisiana, Texas, and Hawaii, excluding Florida) are in the higher cost groups, putting these states at a competitive disadvantage because about 80 percent of sugar production in the region is produced cheaper than in these areas.

\section{Countries with Net Surplus Production}

Some countries in the region have an excess supply over domestic demand at the existing world price (Table 2). In general, the South American and Central American countries tend to have low production costs and, at the same time, are net-surplus producers. These countries have the potential for exporting more sugar to the United States. Other countries in the region export sugar primarily based on preferential arrangements. That is the case of the Caribbean area. In addition to their access to U.S. preferential prices under the Caribbean Basin Initiative (CBI), the region exports sugar to Canada under CARIBCAN and to the European Union under the African/Caribbean/Pacific (ACP) protocol. Current WTO negotiations, however, are crucial to the survival of the Caribbean sugar industry because their high production costs (4-5 times higher than the world price in 2002) make sugar from the region uncompetitive under free trade scenarios (Northover and Thomas, 2002, pp. 102, 111).

\section{Current U.S. Sugar Policy}

Sugar policy in the United States is made up of three elements:

1. obligations under WTO (http://edis.ifas.ufl.edu/SC055), especially minimum access on imports of raw and refined sugar.

2. obligations under NAFTA (http://edis.ifas.ufl.edu/SC035), which cover sugar imports from Mexico.

3. U.S. sugar program under U.S. Farm Act (http://edis.ifas.ufl.edu/SC020; http://edis.ifas.ufl.edu/SC056).

Under the WTO, the United States agreed to import at least 1.256 million short tons of sugar per marketing year. Imports from Mexico under NAFTA were restricted to net surplus production in the low-tier tariff exports, currently at 0.625 cent per pound of raw sugar, until fiscal year (FY) 2000. From FY 2001 through FY 2007, duty-free access was set at a maximum of 250,000 metric tons. Starting in FY 2008, there will be no quantity limit.

General provisions under the 2002 U.S. Farm Act (http://edis.ifas.ufl.edu/SC056) include:

- loans made to processors of cane sugar at 18 cents per pound and processors of beet sugar at 22.9 cents per pound.

- operation of the program at no cost to the federal government (no forfeitures).

- flexible marketing allotments for sugar.

- a system of tariff-rate quotas (TRQ) for foreign imports.

\section{Modeling Potential Future Outcomes}

\section{The Assumptions}

The USDA Report (Haley, 2004) assumes that two types of increased sugar access are possible:

1. The United States modifies its TRQ import regime by increasing sugar quota allocations made to sugar exporters in the hemisphere. Results: a continuation of the support to domestic prices higher than world levels and to hemispheric exporters at least not lower than world prices.

2. The United States permits duty-free sugar imports from the hemisphere without upward quantity limit.

The model analyzes four potential scenarios for the period 2008-2012, with the first two occurring under the current U.S. sugar program: ${ }^{6}$

1. The United States retains its TRQ regime, but doubles the quota access (except for Mexico's 7,258 metric tons) raw value (MTRV) to 708,283 MTRV, considered a moderate increase.

2. The United States retains its TRQ regime, but increases the quota access by 2.0 million MTRV, with allocations to countries outside the Western 
Hemisphere at FY 2001 levels, considered a large increase.

3. The United States allows duty-free access to hemispheric producers with no quantity limits. Results: the U.S. sugar program is abandoned, and the domestic price drops to a marketing margin of 2 cents per pound above the world price, which remains unchanged after the U.S. liberalization.

4. Same as the above scenario, but the world price is assumed to increase by 2 cents per pound (a 22 percent increase) due to increased U.S. import demand.

\section{The Results}

\section{TRQ outcomes with an 18-cent loan rate:}

- Under the baseline model's price assumptions (e.g., 18-cent loan rate until 2010), Commodity Credit Corporation (CCC) sugar stockholding is likely to be a major factor through 2010, when a price equilibrium above the minimum price (to avoid forfeiture) is finally achieved.

- The effect of increasing hemispheric market access is to keep prices at the minimum level (20.17 cents per pound) through loan forfeitures that channel excess production to the CCC. Even in the moderate double-access scenario (hemispheric quota access, except Mexico's, is doubled), CCC stocks in 2012 are projected at 79 percent of the additional market access $(615,000$ short tons, raw value, STRV). In the 2-million-MTRV scenario, CCC stocks in 2012 are projected at 1.95 million STRV, or 88 percent of the increased import access amount.

- Domestic sugar production decreases relative to the base primarily because of reduced planting due to USDA's Payment-in-Kind Diversion Program (http://edis.ifas.ufl.edu/SC056).

- Imports from Mexico are not much affected because U.S. sugar prices are about the same as in the base scenario.
2. TRQ outcomes with lowered loan rates:

- For the double-access scenario, lowering the loan rate to 15 cents per pound yields zero forfeiture to the CCC for all years 2010 through 2012. For the 2-million-MTRV scenario, lowering the loan rate to 13 cents per pound allows CCC holdings to reach zero by 2010, with holdings as high as 1.369 million STRV in the first year of the FTAA.

- The above two scenarios (double access and 2-million-MTRV) show a similar dynamic pattern in their results: increased imports lower sugar prices; U.S. production decreases the succeeding year; sugar prices then rise, but U.S. production does not increase because abandoned mills and processing facilities are assumed permanently closed. Price dynamics move U.S. sugar supply from domestic to foreign sources but, because the imports are capped by the TRQ system, prices recover eventually and sustain U.S. producers and processors who survived the intervening price downturn.

\section{Outcomes under unrestricted FTAA access:}

- The third scenario is equivalent to unrestricted free trade of sugar for the United States; the reasons being that the net surplus producer status of the hemisphere is extremely large, and lowest-cost producers have transport costs lower than non-hemispheric competitors.

- Domestic price level will be closer to world price levels, and changes in U.S. prices will be highly correlated with changes in corresponding world prices.

- The price dynamics associated with the first two scenarios is no longer present. U.S. producers and processors must have low costs to survive in niche sugars because domestic production will be practically terminated. 
- The fourth scenario is similar to the third, but domestic production will not be totally wiped out, although the challenge will be tough. The remaining domestic producers will be subject to the high volatility of the world market. Their survival with assistance is questioned.

\section{Conclusions}

The main conclusions of the USDA Report (Haley, 2004) are divided into two parts. The first corresponds to the current conditions governing the U.S. sugar industry and the assumptions and results concerning the TRQ system. The second part relates to the FTAA potential impacts themselves. Says the Report:

Analysis shows the United States to be a relatively high-cost sugar, although U.S. producing regions (Florida and Eastern sugar beet-producing areas) have costs that are competitive with cost-efficient hemispheric producers. The hemisphere as a whole is a large net surplus producer of sugar and could meet all U.S. sugar needs. The effect of an FTAA would depend on whether increased access was capped under a TRQ system or unlimited. Under a TRQ system, increased imports could cause sugar forfeitures to the CCC. Keeping the current loan program and controlling U.S. Government budget exposure might require a lowering of the loan rate, especially for higher levels of FTAA sugar access.

The second part of the conclusions of the Report presents a very negative impact on the U.S. sugar industry, even when they do not include the potential for its complete disappearance:

Analysis of the FTAA shows that under a TRQ system, U.S. sugar prices recover to pre-access levels but imports permanently replace some U.S. production. In effect, harm to surviving U.S. sugar producers is temporary and is felt only during the transition to increased sugar imports resulting from the FTAA. In the case of unlimited FTAA access, surviving U.S. producers must absorb world price movements and face constant competition with the hemispheres most cost-efficient exporters. Sugar imports would likely constitute over 70 percent or more of all sugar consumed in the United States.

Although results do not indicate consumption shifts away from HFCS, these results are dependent on raw sugar prices at or higher than 9 cents a pound.

In summary, potential impacts of the FTAA on the U.S. sugar industry appear to be dependent on the nature of the TRQ system. If increased access is capped, there will be some forfeitures to the CCC (perhaps from areas other than Florida and Eastern sugar beet-producing states), resulting in lowering the loan rate. That result is also predicted by Schmitz and Schmitz (2005) due to substantial oversupply situations. Under unlimited access, U.S. domestic price stability will disappear for surviving producers and consumers, with imports accounting for more than 70 percent of all sugar consumed in the United States.

\section{References}

Alvarez, José. 2002. Sugar and the 2002 U.S. Farm Bill. Electronic Data Information Source (EDIS) SC056. Department of Food and Resource Economics, University of Florida, Gainesville, FL. http://edis.ifas.ufl.edu/SC056.

Alvarez, José. 2002. Sugar and the World Trade Organization (WTO): Major Issues. Electronic Data Information Source (EDIS) SC055. Department of Food and Resource Economics, University of Florida, Gainesville, FL. http://edis.ifas.ufl.edu/SC055.

Alvarez, José and Leo C. Polopolus. 2002. The Sugar Program: Description and Debate. Electronic Data Information Source (EDIS) SC020. Department of Food and Resource Economics, University of Florida, Gainesville, FL. http://edis.ifas.ufl.edu/SC020.

Alvarez, José, Leo C. Polopolus, and William A. Messina, Jr. 2002. Sugar and the North American Free Trade Agreement. Electronic Data Information Source (EDIS) SC035. Department of Food and 
Resource Economics, University of Florida,

Gainesville, FL. http://edis.ifas.ufl.edu/SC035.

Economic Research Service. 2004. U.S. Agriculture and the Free Trade Area of the Americas. Agricultural Economic Report No. 827, United States Department of Agriculture, Washington, D.C.

(March).

Haley, Stephen L. 2000. Conceptual Overview of the U.S. Sugar Baseline: Incorporating the Effects of the North American Free Trade Agreement. Sugar and Sweetener Situation and Outlook. SSS-227, Economic Research Service, United States Department of Agriculture, Washington, D.C. (January, pp. 11-19). http://www.ers.usda.gov/publications/so/ view.asp?f=specialty/sss-bb/

Haley, Stephen. 2004. U.S. Sugar in the FTAA, Chapter 4, in U.S. Agriculture and the Free Trade Area of the Americas. Agricultural Economic Report No. 827, United States Department of Agriculture, Washington, D.C. (March, pp. 67-80). http://www.ers.usda.gov/publications/aer827/ aer827d.pdf.

Haley, Stephen, and Nydia Suarez. 2004. Sugar and Sweetener Situation and Outlook Yearbook.

SSS-204, Foreign Agricultural Service, United States Department of Agriculture, Washington, D.C. (July). http://www.ers.usda.gov/publications/so/ view.asp?f=specialty/sss-bb/.

Interagency Agricultural Projections Committee. 2002. USDA Agricultural Baseline Projections to 2011. Staff Report WAOB-2002-1, United States Department of Agriculture, Washington, D.C. (February). http://www.ers.usda.gov/publications/waob021/ waob20021/pdf.

LMC International. 2000. The LMC Worldwide Survey of Sugar and HFCS Production Costs. Oxford, UK: LMC Intl (December).

Moss, C., and A. Schmitz. 2002. Vertical Integration and Trade Policy: The Case of Sugar. Agribusiness: An International Journal 18,1:49-60.
Northover, Patricia, and Clive Y. Thomas. 2002. CARICOMs Sugar in the New Liberal Trade Order. Sugar and Related Sweetener Markets: International Perspectives, edited by Andrew Schmitz, Thomas H. Spreen, William A. Messina, Jr. And Charles B. Moss, pp. 101-112. Oxon, UK: CABI Publishing.

Schmitz, Andrew, and Troy G. Schmitz. 2005. Bilateral and Regional Free Trade Agreements and the Economics of Sugar. International Sugar Journal (forthcoming).

\section{Additional Notes:}

3. This section contains a summary taken from Haley (2004). Readers interested in more specific information are encouraged to consult the original source.

4. See Haley (2000) and Interagency (2002) for additional information on the USDA U.S. sugar baseline model.

5. The fourth (high cost) group is not considered for obvious reasons, but it includes Barbados, Dominican Republic, Jamaica, St. Kitts, Trinidad, Hawaii-USA, Uruguay, and Venezuela. These countries show average production costs of 23.56 cents per pound, but contribute only 6 percent to total hemispheric sugar production. Beet sugar production costs in the United States are not considered in this fact sheet because, although it falls among the world's least-cost producers of beet sugar, its costs are still high relative to cane-sugar costs in the hemisphere.

6. Because of this fact, a number of additional assumptions (based on the Farm Act's stipulations) are necessary. For simplicity, the interested reader is referred to the original source (Economic Research Service, 2004). 
Potential Impact of the Free Trade Area of the Americas on the U.S. Sugarcane Industry

Table 1. Current time-frame for negotiations, Free Trade Area of the Americas (FTAA).

\begin{tabular}{|c|c|}
\hline Date & Event \\
\hline December 1994 & FTAA initiated at the Miami Summit of the Americas \\
\hline June 1995 - September 1998 & Structure, scope, and organization of the negotiations determined \\
\hline September 1998 & Negotiations initiated \\
\hline September 1998 - November 1999 & Annotated outlines of the FTAA agreement developed \\
\hline November 1999 - April 2001 & Draft of text of the FTAA agreement developed \\
\hline April 2001 - May 2002 & $\begin{array}{l}\text { Draft text consolidated and methods and modalities for market } \\
\text { access negotiations established }\end{array}$ \\
\hline May 2002 & Market access negotiations initiated \\
\hline December 15, 2002 - February 15, 2003 & Initial market access offers presented \\
\hline February 16, 2003 - June 15, 2003 & Requests for improvement in initial offers presented \\
\hline July 15,2003 - Date to be determined & Revised market accessoffers to be presented \\
\hline January 2005 & Deadline to conclude negotiations \\
\hline December 2005 & FTAA scheduled to enter into effect \\
\hline
\end{tabular}

Table 2. Net surplus status (average sugar production and consumption) of countries negotiating the FTAA by region, 1995-1996 to $1999-2000$.

\begin{tabular}{|lccc|}
\hline \hline \multicolumn{1}{c}{ Region } & Production & Domestic Production & Net Surplus Production \\
\hline United States & 7,260 & 8,913 & $(1,653)$ \\
Other North America & 5,117 & 5,530 & $(413)$ \\
Caribbean & 922 & 619 & 303 \\
Central America & 3,219 & 1,380 & 1,839 \\
South America & 23,049 & 14,702 & 8,347 \\
Total & 32,307 & 22,231 & 10,902 \\
\hline Source: Adapted from Economic Research Service (2004, p.71). & \\
\hline \hline
\end{tabular}

